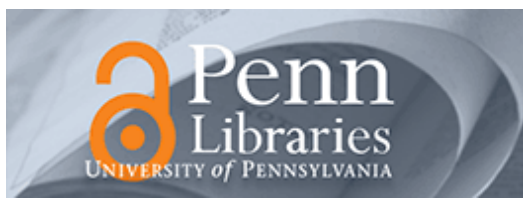

University of Pennsylvania
ScholarlyCommons

Miscellaneous Papers

Miscellaneous Papers

$5-2011$

\title{
Francis Hutcheson: Why Be Moral?
}

Doug Paletta

University of Pennsylvania, paletta@sas.upenn.edu

Follow this and additional works at: https://repository.upenn.edu/miscellaneous_papers

Part of the Ethics and Political Philosophy Commons, and the History of Philosophy Commons

Paletta, Doug, "Francis Hutcheson: Why Be Moral?" (2011). Miscellaneous Papers. 14.

https://repository.upenn.edu/miscellaneous_papers/14

This article has been accepted for publication by Edinburgh University Press in the Journal of Scottish Philosophy, Aug 2011, vo. 9, No. 2: 149-159,

https://doi.org/10.3366/jsp.2011.0013

This paper is posted at ScholarlyCommons. https://repository.upenn.edu/miscellaneous_papers/14

For more information, please contact repository@pobox.upenn.edu. 


\title{
Francis Hutcheson: Why Be Moral?
}

\begin{abstract}
Like all theories that account for moral motivation, Francis Hutcheson's moral sense theory faces two related challenges. The skeptical challenge calls into question what reasons an agent has to be moral at all. The priority challenge asks why an agent's reasons to be moral tend to outweigh her non-moral reasons to act. I argue a defender of Hutcheson can respond to these challenges by building on unique features of his account. She can respond to skeptical challenge by drawing a direct parallel between an agent's reasons to pursue natural, selfdirected goods and her reasons to pursue moral goods. This parallel, however, makes establishing the significance of morality difficult. Given this difficulty, a separate aspect of Hutcheson's account, the additional weight given to benevolence in our assessment of mixed actions, can be used to respond to the priority challenge.
\end{abstract}

\section{Keywords}

Francis Hutcheson, Scottish philosophy, moral motivation, moral sense theory

\section{Disciplines}

Ethics and Political Philosophy | History of Philosophy

\section{Comments}

This article has been accepted for publication by Edinburgh University Press in the Journal of Scottish

Philosophy, Aug 2011, vo. 9, No. 2: 149-159, https://doi.org/10.3366/jsp.2011.0013 


\section{Francis Hutcheson: Why Be Moral? ${ }^{* 1}$}

One of Francis Hutcheson's chief philosophical projects centered on showing, against Mandeville and Hobbes, that both self love and benevolence motivate people to act. These two sources of motivation further map onto two ways agents approve of actions. Interestedly, agents approve of actions that produce pleasure or advantage. Agents also have the capacity to approve or disapprove of actions both distinct from "immediate pleasure" (Hutcheson [1726] 2004: 100) and independent from any advantage to the approver. Hutcheson refers to the latter as the moral sense and uses it to determine at the content of morality. Most commentary on Hutcheson's account of moral motivation focuses on a potential conflict between moral assessment and motivation. In part because Hutcheson believed "neither Benevolence nor any other Affection or Desire can be directly raised by Volition" (Hutcheson [1726] 2004: 139), commenters, like John Bishop, Stephen Darwall and Henning Jensen, tend to focus on a traditional challenge to internalism (Bishop 1996; Darwall 1997; Jensen 1971). Namely, if only desires motivate and they are nonvolitional, how can knowing what acts are good generate a desire to motivate the act?

Rather than focus on the causal and cognitive mechanisms that explain how an agent can act morally, I will address why, on Hutcheson's account, she should tend to prioritise acting that way. ${ }^{2}$ In particular, I want to see if the account can respond to a pair of challenges facing accounts of moral motivation. The first challenge invokes a skeptical worry about whether we have any reason to be moral at all. The second focuses on the importance of morality. Can Hutcheson's account explain the relative importance that moral considerations have over other considerations? Hutcheson's version of moral sense theory has unique features that enable it to respond to each objection. ${ }^{3}$

To show how Hutcheson can account for why we should be moral, I begin by briefly outlining his moral sense theory (I). With his account in hand, I turn to the pair of challenges (II). Hutcheson's account can handle the skeptical challenge by drawing a parallel between the reasons an agent has to be moral and her reasons to act self interestedly. However, this response fails to explain why the pursuit of moral goods should generally have priority over the pursuit of self interest (III). One potential response moves Hutcheson towards his predecessor the Third Earl of Shaftesbury by arguing that acting morally is better for you. However, the difference between Hutcheson and Shaftesbury's metaphysics make this move problematic. Ultimately, I argue that Hutcheson can solve the problem by appealing to a feature of his account of moral assessment of mixed actions - the increased weight afforded to benevolence over self love (IV).

Hutcheson makes several claims about the moral sense that shape his account of what moral goodness is and how we, as humans, identify it. As mentioned above, the moral sense is

\footnotetext{
* This article has been accepted for publication by Edinburgh University Press in the Journal of
} Scottish Philosophy, Aug 2011, vo. 9, No. 2: 149-159, https://doi.org/10.3366/jsp.2011.0013 
roughly a capacity to experience a particular type of approbation or disapprobation. Moreover, the moral sense is a sense and not a form of reasoning (Hutcheson [1726] 2004: 100). In part because of this, Hutcheson states, "We are not to imagine, that this moral Sense, more than the other Senses, supposes any innate Ideas, Knowledge or practical Proposition" (Hutcheson [1726] 2004: 100). The moral sense does not contain a principle of morality itself. However, principles may be introduced to describe this sense in the same way that scientific principles can be introduced to describe how we see. In both cases, the adequacy of the principles depends on what the respective sense apprehends. Luigi Turco sums up the nature of the moral sense by saying, "it is independent of our will, is common to mankind and, above all, it is immediate, that is to say, its deliverances are not conclusions mediated by premises" (Turco 2003: 138).

Having a moral sense allows humans to distinguish at least two different types of good: natural good and moral good. According to Hutcheson, "nothing is Advantageous or naturally Good to us, but what is apt to raise Pleasure mediately, or immediately" (Hutcheson [1726] 2004: 86). We determine what is naturally good by using the sense of pleasure. Natural goods are those things that give us pleasure. Determining what gives us pleasure in turn establishes what is in our interest. Due to the relationship between interest and natural goods, "natural Goods are pursu'd from Interest, or Self-Love" (Hutcheson [1726] 2004: 86). Since natural goods are constituted by what tends to bring an individual pleasure, an agent is motivated to obtain natural goods in order to benefit herself.

Where the sense of pleasure determines natural goods, moral goods are apprehended by the moral sense. Hutcheson states, "the Word Moral Goodness, in this Treatise, denotes our Idea of some Quality apprehended in Actions, which procures Approbation, and Love toward the Actor, from those who receive no Advantage by the Action" (Hutcheson [1726] 2004: 85). In order for the moral sense to provide this distinct type of approbation, Hutcheson must describe a quality that generates approval regardless of whether it advantages the agent. Hutcheson asserts that the quality is roughly "useful[ness] to Mankind" (Hutcheson [1726] 2004: 98) or promoting the general good. Rather than self love, which seeks to advantage the agent, benevolence motivates moral acts by aiming to promote the general good. ${ }^{4}$

Important for the later discussion, sometimes self love and benevolence jointly motivate an agent to perform an act, though the sources of motivation remain distinct (Hutcheson [1726] 2004: 104). Insofar as self love motivates an agent, she acts to benefit herself. Insofar as benevolence motivates her, she acts to promote public good (Hutcheson [1726] 2004: 104). This distinction provides the basis for the different ways someone can approve of an act. An act performed from benevolence elicits moral approbation. While benevolent acts are morally good, "we may find out some ground, even from the Views of Interest, to approve the same Actions which every Man admires as soon as he hears of them ... [but this approval is] under a quite different Conception" (Hutcheson [1726] 2004: 94) of approval than the one arising from the moral sense. That is, an agent can interestedly approve of an act because it advantages her and morally approve of it because it benefits mankind. Even though self love and benevolence can 
motivate an agent to perform the same action, the act will only be morally praiseworthy if performed from benevolence.

So, Hutcheson provides an account that distinguishes moral goods from natural goods. A natural good is a private good pursued from self love. A moral good is a good pursued from benevolence that benefits mankind. Hutcheson clarifies what benefits mankind through a utilitarian principle that describes what is apprehended by the moral sense. Moreover, while self love and benevolence may motivate an agent to pursue the same act, only benevolent acts generate moral approbation.

\section{II}

An account that explains why we should be moral ought to meet two related challenges. The skeptical challenge roughly proceeds as follows: an adequate moral theory should explain why, from her perspective, an agent should be moral. Determining that an act is good does not itself necessarily give an agent a reason to act. Why should she care about the demands of morality? The priority challenge focuses on a related topic - the importance of morality. In order to meet the priority challenge, a moral theory should not only be able to explain why people have some reason to be moral but also why moral considerations should generally have priority over their other considerations. The way a theory responds to the priority challenge frequently depends on how it answers to the skeptical challenge.

Mounted against Hutcheson, the skeptical challenge contends that his account does not explain why, from the agent's perspective, she should act morally. Appealing to either of the two fundamental sources of motivation, self love and benevolence, seems problematic. Having argued that only benevolent actions are morally praiseworthy, the reason to perform benevolent actions cannot be grounded in self interest. Doing so would undermine the moral praiseworthiness of the acts. Prima facie, explaining the reasons an agent has to be moral in terms of the pleasure she receives from acting morally grounds the motivation in self interest. Thus, appealing to pleasure in order to explain the reasons an agent has to act benevolently threatens to undermine the moral praiseworthiness of those seemingly benevolent actions.

Alternatively, Hutcheson cannot appeal to the moral sense in order to explain why someone should be moral. The question just is why she should follow the recommendations of the moral sense. These considerations help to show the nature of the challenge. The question 'why be moral?' goes beyond whether the moral theory calls on someone to act morally. Rather, the skeptical challenge is concerned with whether agents have any reason to act morally in the first place. Moreover, the response to the challenge should not undermine the moral praiseworthiness of the act by reducing moral motivation to pursuing pleasure.

The priority challenge puts pressure on the account in a different way. Roughly, according to the priority challenge, an account should try to do more than establish that we have some reason to be moral. The account should further explain why pursuing moral goods tends to have priority over pursuing natural goods. This challenge still focuses on the reasons an agent has to be moral. Where the skeptical challenge puts pressure on Hutcheson's account to explain 
what reasons an agent has to be moral at all, the priority challenge calls for an explanation that accounts for why an agent's reasons to be moral tend to outweigh her nonmoral reasons to act.

Moral sense theorists may reject the need to address the priority challenge. After all, if our experience with morality comes from sense and sentiments, the question of priority appears to be largely empirical. So long as most people act morally most of the time, what more can be said to respond to the priority challenge. At a minimum, however, a moral sense theory that responds to the challenge by providing a more principled answer is prima facie better than one that does not. Hutcheson's moral sense theory can respond to these challenges.

\section{III}

Hutcheson does not provide an explicit answer to either challenge. In the section of his Inquiry titled "Concerning the immediate Motive to virtuous Actions," Hutcheson is more concerned with showing that benevolent acts are possible than explaining why someone should act out of benevolence. Hutcheson argues that we can act benevolently and that we sometimes do act benevolently (Hutcheson [1726] 2004: 112-115). However, since neither of the challenges questions whether we can act benevolently, a defender of Hutcheson will have to build on his account to respond to these challenges. The skeptical challenge, when applied to the question of why we should be moral, does not challenge morality itself. Rather, the question puts pressure on why we should act as morality dictates. That is, the challenge grants Hutcheson's account of moral goodness as well as the claim that we can be moved by benevolence and self love. Drawing a parallel between the reason an agent has to act morally and the reason an agent has to act self interestedly responds to the skeptical challenge.

What reason does someone have to pursue natural goods? The reason an agent has to pursue natural goods depends on the relationship between the goods and the agent. When an agent pursues a natural good, she pursues that which tends to generate some private pleasure. The reason to pursue private pleasure is grounded in love or esteem for oneself. That is, the reason someone should pursue her own pleasure is that she loves herself. Moreover, each person does love herself. Hence, each person has reason, from her own perspective, to pursue natural goods. This point is further corroborated in Hutcheson's account by the relationship between pleasure and interest. Since that which is apt to bring about pleasure defines what is in our interest, when someone acts to promote her pleasure she also acts in her own interest. Self love provides a reason for each person to pursue natural goods. Each agent loves herself, and pursuing natural goods is the best way for her to get that which tends to bring her pleasure.

A defender of Hutcheson can explain the reason each person to act morally, from her perspective, by following a similar line of reasoning. What reason does someone have to pursue moral goods? Pursuing moral goods involves pursuing that which tends to promote the greatest happiness for the greatest number. The reason to promote the greatest happiness for the greatest number is grounded in love or esteem for others. Moreover, agents love others (Hutcheson [1726] 2004: 102). Hence, each agent has a reason, from her own perspective, to act morally. Namely, pursuing moral goods is the way for each agent to act on her love for others. 
Meeting the skeptical challenge by appealing to agent's love of others is a good way to respond to the challenge for at least three reasons. First, as presented, the skeptical challenge attacks Hutcheson's account of moral motivation, not his account of human nature. This line of response to the challenge against Hutcheson's account of moral motivation builds on the importance of his section about how human motivation works. By defending the claim that we do act benevolently, Hutcheson defends the empirical claim needed to explain why someone should act morally. Second, grounding an agent's reasons to act morally in the agent's love of others does not reduce the reason an agent should act morally to the pursuit of pleasure. By avoiding this reduction, the response preserves the moral praiseworthiness of actions performed on this basis. Finally, the reason to pursue moral goods has a structure paralleling that of the reason to pursue natural goods. If love of others is not an adequate basis for explaining why someone should pursue moral goods, then self love will not be an adequate basis for explaining why she should pursue natural goods.

While the symmetry between self love and benevolence allows Hutcheson's account to respond to the skeptical challenge, it plays into the worry presented by the priority challenge. Among the strengths of the response to the skeptical challenge is the direct parallel between the reasons to act morally and the reasons to pursue natural goods. Given this parallel, however, the reasons to act morally are put on the same footing with the reasons to act for self interest. Since they are on the same footing, the reason to be moral does not appear to have priority over the reason to pursue self interest. At least three ways of modifying Hutcheson's account to address the priority challenge encounter problems. First, moving towards Shaftesbury, Hutcheson could appeal to a metaphysical difference between moral goods and natural goods. Second, Hutcheson could follow Shaftesbury by claiming that agents should act benevolently because doing so is most apt to bring them happiness. Finally, Hutcheson could make an empirical claim about the sources of motivation that love of others almost always is stronger than self love. Briefly addressing each sets standards for a successful response.

Though Hutcheson famously follows Shaftesbury with his moral sense theory, he approaches the moral sense in a very different way. Again, for Hutcheson the moral sense is a sense, and we discover moral principles in the same way we discover optical principles, by looking to experience. Shaftesbury does not have such an empirical approach. Shaftesbury allows that actions motivated by self love may be virtuous so long as that action promotes the "general system" (Shaftesbury [1711] 1999: 169) created by God. These actions may still be virtuous because in promoting God's general system they promote an independently good moral order. Each person has a reason to be good and to prioritise good actions because doing so promotes God's general system. That is, good actions are different in kind than not good actions, and this difference, that they promote God's general system, potentially responds to the priority challenge. Since Hutcheson, instead, approaches the moral sense the same way someone might approach optics, he cannot avail himself of such a response. While pursuing moral goods elicits a different kind of approbation than pursuing natural goods, neither type of approbation is 
metaphysically better. That would be like calling taste better than smell. Without some further story or goal, scent is not better or worse than taste.

Moving towards Shaftesbury in another way could create a second problem. In order to explain why we should promote the general system, Shaftesbury argues for "an obligation to virtue consisting in the fact that the virtuous life realised the agent's good" (Darwall 1995: 208). Hutcheson praises the project of showing the convergence of morality and interest and sometimes presents a similar argument. He partly accounts for the importance of the moral sense by contending "that [the moral sense] gives us more Pleasure and Pain than all our other Facultys" (Hutcheson [1726] 2004: 162). However, this affinity between Hutcheson and Shaftesbury cannot solve the problem. Noting a difference between Hutcheson and Shaftesbury, Grote states:

Unlike Shaftesbury, Hutcheson refuses to admit any fundamental distinction between affections toward private interest and affections towards which we are led by a desire for the pleasures of virtue itself. In so far as both types have as their end the attainment of pleasure, however sublime, Hutcheson considers them both self interested (Grote 2006: 167).

Acting morally in order to realise an agent's good or experience virtuous pleasure reduces moral motivation to interested motivation. Modifying his account in this way would undermine a special feature of Hutcheson's account - the independence of benevolence - and potentially undermine the praiseworthiness of benevolent actions. Hutcheson cannot solve the priority problem by arguing that we should be benevolent in order to be happy.

Finally, the account may rely on an empirical response to the priority challenge. Perhaps most agents' love of others is stronger than their self love. If an agent's love of others is greater than her self love, then she seems to have a strong reason, as well as motivation, to act morally rather than self interestedly. That is, her pursuit of moral goods should tend to take priority over her pursuit of natural goods since her love of others is stronger than her self love. Unlike the second move, this response does not explain the priority of the pursuit of morality by appealing to the amount of pleasure procured by pursuing moral goods.

The empirical response to the priority challenge faces two related problems. First, according to the response, the priority of the pursuit of morality is contingent on the relative strength of the two types of love in each agent. As such, the response does not provide an in principle basis for establishing the priority of morality. Second, the claim that most agents have stronger love for others than for themselves is not obvious. As Turco bluntly puts it: "benevolence . . . is weaker than self-love" (Turco 2003: 137). If the only way to establish the priority of the pursuit of morality depends on the relative strength of the two types of love, then the defender of Hutcheson has a difficult case to make. Both of these problems point to the fact that the proposed response to the priority challenge relies on an empirical claim. While empirical 
findings may support the claim that an agent's love of others outweighs her self love, the findings may turn out to support the opposite claim.

Though putting benevolence on the same footing as a fundamental motivating desire provides a ready answer to the skeptical challenge, doing so opens Hutcheson's account to the priority challenge. By basing his account of moral goodness on the moral sense alone, Hutcheson cannot respond to the priority challenge by appealing to a metaphysical difference between the importance of moral and natural goods or to the pleasure produced by securing each. Moreover, an empirical response provides only a weak response to the challenge. The response does not establish that moral considerations should tend to trump nonmoral ones. Instead, it argues that moral considerations are not precluded from doing so. Again, a defender of Hutcheson can consistently respond to the skeptical challenge while leaving the priority challenge up to the empirical question. All things equal, however, an account that provides some sort of response beyond this empirical one will be on better footing to respond to the challenges.

\section{IV}

The neat symmetry between natural and moral goods, as well as the motivational basis for each, precludes a response to the priority challenge that contrasts the two sides against one another. Rather than compare actions motivated purely by self love against actions motivated purely by benevolence, I propose the solution to the priority problem lies in examining actions motivated by both, Hutcheson's so called mixed actions. Again, mixed actions are those jointly motivated by Hutcheson's two fundamental sources of motivation: self love and benevolence. The structural similarity behind the motivation and assessment of pure actions breaks down in mixed cases. As Darwall leaves the problem at the end of his article "Hutcheson and Practical Reason," when "the agent prudentially ought to do A and morally ought to do B ... [s] hould she do what she prudentially ought? Or should she do what she morally ought?" (Darwall 1997: 87). While looking at mixed actions does not permanently settle this question, doing so gives some reason to prioritise acting morally.

Granting Hutcheson's two sources of motivation, mixed actions seem to be a particularly prevalent category of action. Most social interactions, like teaching, are unlikely to be motivated purely by self love or benevolence. Rather, deciding to teach (and what to teach) is partly driven to secure natural goods for myself, like esteem, and partly driven by an effort to teach important things to students while developing their critical skills. Most decisions in social circumstances include these two types of considerations. As part of a social group, what will I get out of the decision? But also, as part of this social group, what decision will be best for the group as a whole? If most social interactions have this dual structure with both self regarding and other regarding motivation, then we have a particularly strong reason to pay attention to mixed actions.

In the Inquiry, Hutcheson describes how we assess mixed actions. He states:

if a Man have such strong Benevolence, as would have produc'd an Action without any Views of Self interest; that such a Man has also in View private 
Advantage, along with publick Good, as the Effect of his Action, does no way diminish the Benevolence of the Action. When he would not have produc'd so much publick Good, had it not been for Prospect of Self interest, then the Effect of Self love is to be deducted, and his Benevolence is proportion'd to the remainder of Good, which pure Benevolence would have produc'd (Hutcheson [1726] 2004: 104).

Put differently, when assessing mixed actions, the degree to which benevolence motivates the action, even when self interest is also necessary, is given full measure. So, if a jointly excited act could have been excited by either benevolence or self love, but in fact is excited by both, we assess the act as benevolent.

Taken together, we have some reason to think mixed actions are prevalent, particularly in our social interaction. Moreover, while the sources of motivation for these types of actions have a similar structure, the approval elicited falls squarely on the side of moral approbation. Unlike pure cases, where interest approves of self loving acts similarly to how the moral sense approves of benevolent acts, in mixed cases benevolence has more weight than self love. All things equal, the asymmetry in the approval of mixed actions provides some reason to give considerations of benevolence more weight than considerations of self love because the moral sense approves of these actions more strongly than interest. While this does not guarantee that benevolence will trump self love, it can explain why, all things equal, considerations of benevolence should be more pressing than considerations of self love.

Establishing priority by appealing the asymmetry in the assessment of actions has three significant advantages. Doing so locates the basis of priority in the agent, does not reduce moral motivation to interested motivation, and provides an in principle basis for prioritizing benevolence. Avoiding the first problem with a potential move towards Shaftesbury, this response to the priority challenge does not invoke an external account of goodness. Rather than refer to good states of affairs, a Hutchesonian can overcome the priority challenge by examining motivation and assessment. Avoiding the second problem with a potential move towards Shaftesbury, relying on the asymmetry in assessment does not reduce the motivation to be moral to self love, maintaining a key distinguishing feature of Hutcheson's account. Finally, the proposed basis of priority is structural. Regardless of the particulars of Hutcheson's account of moral psychology or the empirical make up of any individual, Hutcheson's moral sense theory can provide an all things equal presumption in favor of acting morally from the relationships between benevolence, self love, pleasure and moral assessment.

Like all moral theories, Hutcheson's moral sense theory faces two related challenges. It must both be able to explain what reasons an agent has to be moral and to do so in a way that accounts for the importance or priority of morality. Hutcheson can explain the reason an agent has to act morally by appealing to one of the two fundamental sources of motivation: benevolence. An agent's reason to act morally parallels her reason to pursue natural goods. While this parallel allows Hutcheson to explain why someone should act morally, it makes 
addressing the priority challenge difficult. Fortunately, the assessment of mixed actions includes an important asymmetry that overcomes this challenge.

\section{REFERENCES}

Bishop, John D. (1996) 'Moral Motivation and the Development of Francis Hutcheson's Philosophy', Journal of the History of Ideas, Volume 57, Number 2, pp 277-295.

Darwall, Stephen (1995) The British Moralists and the Internal 'Ought': 1640-1740, Cambridge: Cambridge University Press.

----- (1997) 'Hutcheson on Practical Reason', Hume Studies Volume XXIII, Volume1, pp 73-90. Grote, Simon (2006) 'Hutcheson's Divergence from Shaftesbury', The Journal of Scottish Philosophy, Volume 4, Number 2, pp 159-172.

Hutcheson, Francis [1726] (2004) Inquiry into the Original of our Ideas of Beauty and Virtue, ed. Wolfgang Leidhold, Indianapolis: Liberty Fund.

Jensen, Henning (1971) Motivation and the Moral Sense in Francis Hutcheson's Ethical Theory, The Hague: Martinus Nijhoff.

Scanlon, T.M. (1998) What we Owe to Each Other, Cambridge: Cambridge University Press. Shaftesbury, Third Earl of [1711] (1999) Characteristics of Men, Manners, and Times, ed. Lawrence E. Klein, Cambridge: Cambridge University Press.

Strasser, Mark (1990) Francis Hutcheson's Moral Theory Its Form and Utility, Wakefield, New Hampshire: Longwood Academic.

Turco, Luigi (2003) 'Moral Sense and the Foundation of Morals', in Cambridge Companion to the Scottish Enlightenment, ed. Alexander Broadie, Cambridge: Cambridge University Press, pp 136-156.

\section{NOTES}

${ }^{1}$ Earlier versions of this text were presented at the Spring Ethics Conference in March 2007 at Felician College, with comments by David Morrow, and the $4^{\text {th }}$ International Reid Symposium in September 2007 at Princeton Theological Seminary.

${ }^{2}$ In this paper I use reason in a colloquial sense. I am not referring to Reason as a cognitive faculty or Hutcheson's two technical uses of the term, exciting reason and justifying reason. Roughly, exciting reasons are the desires that motivate an act where justifying reasons explain why an act engenders moral approbation. Justifying reasons cannot elicit action and exciting reasons identify the particular motivations of an actor. When I use the term 'reason,' I instead mean more generally the considerations that are relevant for an agent to take into account given her sources of motivation. These considerations are broader than Hutcheson's exciting reasons because he restricts them to natural goods and self love. Additionally, my sense of reason is different from justifying reasons because they depend on an agential perspective. For more on 
exciting and justifying reasons see: Darwall "Hutcheson on Practical Reason and chapter five of Strasser's Francis Hutcheson's Moral Theory Its Form and Utility.

${ }^{3}$ For a contemporary example of these standards see chapter 4 of Scanlon's What we Owe to Each Other.

${ }^{4}$ For more on the distinction between natural and moral goods see pages 211-216 of Darwall's The British Moralists and the Internal 'Ought'. 